\title{
ELECTRODEPOSITION OF COPPER POWDER FROM MIXTURE SULPHATE -CHLORIDE ACIDIC SOLUTION
}

\author{
Sundus Abbas Jasim
}

Email:sundusabbas2012@yahoo.com

University of Babylon /College of Materials Engineering Metallurgy Department

\begin{abstract}
This paper studies the preparation of Copper powder from Copper Sulphate aqueous solution $\left(\mathrm{CuSO}_{4} .5 \mathrm{H}_{2} \mathrm{O}\right)$, sulfuric acid $\left(\mathrm{H}_{2} \mathrm{SO}_{4}\right)$ and copper chloride $\left(\mathrm{CuCl}_{2} .2 \mathrm{H}_{2} \mathrm{O}\right)$ by using the process of electro-deposition. Process of Powder deposition have been investigated for copper powder, it is a fine layer on cathode electrode by using the value of different from current densities $(0.12,0.14,0.16$, and 0.18$) \mathrm{A} / \mathrm{cm}^{2}$.as it is noticed the weight of the powder rises with there is of current density. Diffractions of X-ray (XRD) revealed high crystallinity and pure copper powder not contain impurity or oxides. Size of the Crystallite has been measured by Scherrer's Formula about (38.44 -43.161) nm. Optical microscopes have revealed the particles of copper have dendritic shapes. The size of Particles analyzer measured the size of a particle which is about $(2.4-8.7) \mu \mathrm{m}$.
\end{abstract}

KEY WORD: Electrodepositing, Current density, current efficiency, Copper sulfate, Copper chloride, XRD, particle shape, particle size.

\footnotetext{
الترسيب الكهربائي لمسحوق النحاس من خليط كلوريد - كبريتات- محلول حامضي جامعة بابل / كلية هندسة المواد جاسم قفم هندسة المعادن

في هذا البحث يتم تحضير مسحوق النحاس من المحاليل المائية المكونة من كبريتات النحاس المائية وكلوريد النحاس المائية (CuSO $\left.4.5 \mathrm{H}_{2} \mathrm{O}\right)$ الكهربائي. نم دراسة عملية الترسيب الكهربائي لمسحوق النحاس، اذ كان على شكل طبقة ناعمة يتكون على قطب وهب

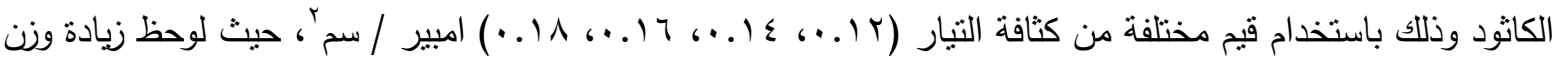
المسحوق المترسب مع زيادة كثافة التيار . اظهر حيود الاشعة السينية الحصول على مسحوق النحاس عالي البلورية

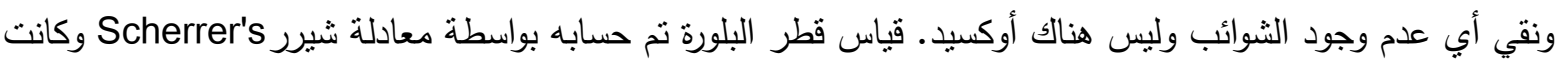

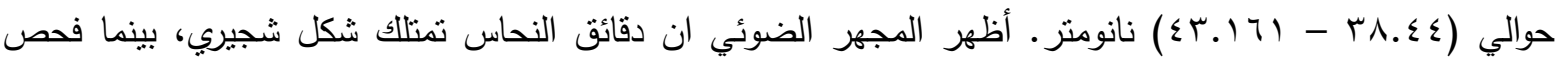

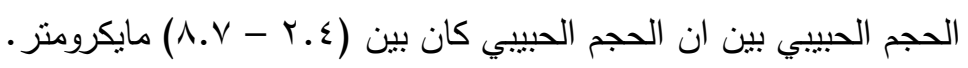
الكلمات المفتاحية: الترسيب الكهريائي، كثافة التيار، كفاءة التيار، كبريتات النحاس المائية، كلوريد التحاس المائي، حيود الاشعة السينية، شكل الدقائق، حجم الدقائق.
} 


\section{INTRODUCTION}

Methods of powder metallurgy have a lot of benefits. Powder could be made from pure raw materials with a good characteristic. This method includes quieter operations and cleaner with longer life of product. In some applications, processes of powder metallurgy have advantages over other methods. Traditional melting and other methods can't produce heavy metal powder that is possible only by the process of powder metallurgy. [S.G.Viswanath, M.M.Juchak,2012] Recently, powder metallurgy improved very fast, both in the quantity and numbers of metal powder produced. In the previous decade, a rise in the productions of uncommon metal powder has been noticed. [Muwafaq Mahi Abd-Alshammari, 2014]

Probably, morphology is one of the most important properties of electrodeposited metal. Mainlyit relies on the kinetic parameter of the depositions processes and the deposition over current or potential densities. Generally, they rely on the shapes and sizes of powders. [M.G.pavlovic,et al,2010]

Thanks to a fast rise in the importance of powders metallurgy, metal powder is made in a large quantity at the present time and a huge portion is produced by electrolysis. [Ali H,Abbar,2008]

Copper powder has been utilized in the industrial application for decades. Pure copper powder has been utilized in electronics and electrical industry due to the outstanding thermal and electrical conductivity. Copper powder is utilized in friction materials and structural parts, Brass, bronz and other copper alloys made by power metallurgy method. [Ali H.Abbar, 2008]

Many studies investigated the copper powders electro-deposition involving:

-Noura Touabiet al 2015, made copper electrodepositions at a graphite electrodes from synthetic $0.05 \mathrm{M}$ copper (II) sulfate solutions, that had $\mathrm{PH}=3$. Sodium chlorides were added to raise the conductivities of the solutions and catalyze the processes. The copper removal percentage and efficiency of the current rise with increasing of the speed of the rotation and at 1500rpm reached a maximum of $94 \%$ respectively after four hours of process. The deposits become purely with the rise of the speed of the rotation. The morphology and structure have changed to delicate deposits featured by dendritic growths.

-S.Q. Vis Wanath and M.M.Jachak, 2012, investigate dsynthesis copper powder by electrodeposition from sulphuric acid and glycerol. Cubical, hexagonal, round shaped particles, and dendritic have been obtained with sizes of more than $85 \%$ particles smaller than $60 \mu$.The apparent densities of copper powders lessened with a rise in concentrations of glycerol. It has been found that in nonexistence of copper sulphates there create some copper depositions on the cathodes. -WANG Ming - Yong et al, 2010, investigated copper powder via super gravities fields were utilized for enhancing electrolytic reactions. The outcomes revealed that current efficiencies of electrolytic copper powder under super gravities field raises by more than $20 \%$ than that under normal gravities conditions. Copper powder sizes lowered with the rise of gravity coefficients.

-Sami I. Jafar, 2009, has studied new organic compound (lanolin) was added to the electrolyte of copper powders deposition units. The visible densities of the produced powders were affected by the copper concentrations, current densities, and certain surfaces. Also the mean grain sizes of powder, deposited powders mass have been estimated .The best concentrations of lanolin is $0.7 \%$ at which grain sizes deposit is fine and smooth (about 93 less than 53micron )and has $99.9 \%$ purity.

The research aims at producing copper powders from ores (copper sulfates, copper chlorides and sulphuric acids) and study the impact of current densities ,current efficiencies ,particles shapes and particle sizes for copper powders because the important of copper powder in used in the field of industry. 


\section{EXPERIMENT PART}

\section{Electrolytic cell}

Glass baker and cylindrical heat-resistant were used to prepare the electrolytic cell used in the present work. The cell consists of copper electrodes and working anode. Electrodes with dimensions $(4 \mathrm{~cm})$ length, $(4 \mathrm{~cm})$ width and $(1 \mathrm{~cm})$ thickness have been prepared using high purity materials $(99 \%)$. Electrolytic cell provided with wooden crossbar to hold the electrodes. Copper wires were used to hang the electrodes in order to immerse them in the solution and to ensure moving location of each electrode inside the cell. Figure (1) shows the electrolytic cell used in the electrodeposition.

\section{Aqueous Solution}

Electrolytic solution preparation produces copper powders. Dissolving copper sulfate $\left(\mathrm{CuSO}_{4} .5 \mathrm{H}_{2} \mathrm{O}\right)$ with distilled water, sulfuric acid $\left(\mathrm{H}_{2} \mathrm{SO}_{4}\right)$ and copper chloride $\left(\mathrm{CuCl}_{2} \cdot 2 \mathrm{H}_{2} \mathrm{O}\right)$ by dependence on the operating conditions.

\section{3-Electrodeposition process}

Electrodeposition process started with installs the distance between the electrode and hang of the electrodes in the specified place. Electric circuit connected with power supply to pass the electrical current at temperature $\left(30^{\circ} \mathrm{C}\right)$. As well as move of the solution during the electrodeposition, process to dispose of the bubbles of hydrogen gas that formed on the electrode surface and this is done using a magnetic stirrer. The chemical reactions are:

$$
\begin{aligned}
& \mathrm{CuSO}_{4} \longrightarrow \mathrm{Cu}^{+2}+\mathrm{SO}_{4}^{-2} \\
& \mathrm{CuCl}_{2} \longrightarrow \mathrm{Cu}^{+2}+2 \mathrm{Cl}^{-} \\
& \mathrm{H}_{2} \mathrm{SO}_{4} \longrightarrow 2 \mathrm{H}^{+}+\mathrm{SO}_{4}^{-2} \\
& \mathrm{Cu}^{+2}+2 \mathrm{e} \longrightarrow \mathrm{Cu}
\end{aligned}
$$

Then note the electro deposition process to produce copper powder. After completing the experiment time, collects the powder deposited on the cathode by using a brush and glass baker.

\section{Washing and drying powder}

Washing powder, which was collected by distilled water and then treated with a solution of sodium bicarbonate $(0.05 \%)$ and sodium tartarate $(6 \mathrm{~g} / \mathrm{L})$. To protect the powder against subsequent oxidation after completion of the process of washing, powder filtered and dry inside the oven at temperature $\left(80^{\circ} \mathrm{C}\right)$ then weighted powder. [Sundusabbasjasim, 2006]

\section{Effect of current density}

It studies the effect of current density on electrodeposition to produce copper powder by taking different values and then note deposition process under those conditions. Table (1) shows operating conditions for effect of current density.

\section{Current efficiency}

Electrolysis laws put by faraday to show the relationship between amount of electric charge pass through solution and amount of deposition on metal surface. So calculate current efficiency from equation: - [Sunil, et al, 2015]

Current efficiency $\%=\frac{W}{\bar{W}} \times 100$ 
$\overline{\mathrm{W}}=\frac{\mathrm{ItM}}{\mathrm{nF}}$

$\mathrm{W}$ : the weight of the metal deposition in experiment

$\bar{W}$ : the weight of the metal deposition in theory

$\mathrm{M}$ : Atomic weight of copper (63.54) $\mathrm{g} / \mathrm{mole}$

I: Current in ampere

$\mathrm{t}$ : time in second

F: Faraday constant (96484.coulombs per mole).

It was also current density calculation through the following law:

$$
\text { Current density }=\frac{\text { current }}{\text { Area }}
$$

\section{Characterizations:}

Copper powder is formed electrodeposition process with different current density has studied its morphology and the shape by optical microscope (Italy - Biolab - 1007). The powder has characterized by the diffraction of X-ray (XRD), type (Shimadzo, XRD6000, diffractometer, Japan). X-rays are generated using Copper $(\mathrm{Cu}-\mathrm{K \alpha})$ radiation at $30 \mathrm{kV}, 40 \mathrm{~mA}$ and wavelength $(\lambda=1.5406 \AA)$, radiations for generating pattern of diffractions from a powder sample at room temperatures in a $2 \theta$ ranges of $20^{\circ}$ to $80^{\circ}$. To determine particle size of copper powder has tested by particle size analyzer (Type Better 20000. [All tests was done in Materials Engineering College laboratories - Babylon University]

\section{RESULTS AND DISCUSSION Electrodeposition Process:}

In electrodeposition process used of acidic solution ( $\mathrm{PH}=1.4)$, component of copper sulfate $\left(\mathrm{CuSO}_{4} .5 \mathrm{H}_{2} \mathrm{O}\right)$, Sulfuric acid $\left(\mathrm{H}_{2} \mathrm{SO}_{4}\right)$ and copper chlorideCuCl $\left.\mathrm{Cu}_{2} .2 \mathrm{H}_{2} \mathrm{O}\right)$, where deposition of copper powder practically by electrolysis. Figure (2) shows copper powder deposited on the surface of cathode electrode, where deposition of copper powder on form of layer fine powder on the surface of cathode electrode. An indication of deposition of copper powder of high current efficiency, as shown in Figure (3).

\section{Effect of current density:}

To show effects of the current densities in electrodeposition process of copper powder as conducting practical experiments depending on the different values of the current density (o.12, $0.14,0.16,0.18) \mathrm{Amp} / \mathrm{cm}^{2}$ in electrolyte cell containing acidic solution from copper sulfate , sulfuric acid and copper chloride at constant temperature and distance between electrodes .

The results showed getting deposition of copper powder, note-increasing weight of the copper powder deposited with increases value of the current density. Figure (4) show effect current density on weight of deposited powder, as its reaches current efficiency $(65.2 \%)$ at value $\left(0.18 \mathrm{Amp} / \mathrm{cm}^{2}\right)$, while reach to the value $(56.7 \%)$ at $\left(0.16 \mathrm{Amp} / \mathrm{cm}^{2}\right)$ and decrease to the value $(49.9 \%)$ at $\left(0.14 \mathrm{Amp} / \mathrm{cm}^{2}\right)$ also reach at $(19.9 \%)$ at value $\left(0.12 \mathrm{Amp} / \mathrm{cm}^{2}\right)$. The increase in the values of current densities make the solution more saturated of ions because increased rate of current passing in electrolyte cell, which leads to the deposition of copper powder on the surface of the cathode electrode. 


\section{Particle shape}

Optical microscope used to determine shape of particle of copper powder Figure (5) show shape of particles of copper powder as show dendritic shape of copper powder in different of values current density. Dendritic shape of copper powder seems to be identical to the standard for copper powder shape in electrodeposition process. Copper powder formed a dendritic shape because of the nucleation on the grains can occurred continuously. Those grains of copper powder and sub particles grain can be produced dendritic growth on nuclei composed on "the initial surface" and the grains themselves. [M.G.Pavlovic, et al, 2010]

\section{X-Ray Diffraction}

XRD can be used to describe the particles crystallinity. XRD patterns of copper powder prepared from aqueous solutions of copper sulphide, copper chloride and sulfuric acid as shown in Figures(6- a, b, c, d) comparing with the standard JCDPS card. Observed diffraction peaks matches well with JCPDS cards No. 04-0836. The diffraction peaks of (111), (200), and (220), are characterized and shown excellent crystal face centered cubic (FCC) structures of copper and no oxides or impurities could be found. [W. Ming et al, 2010]. The crystallite size was identified by XRD for structural limitation and evaluation of crystalline size by using Scherrer's formula at the peak (111):

$\mathrm{D}_{\mathrm{XRD}}=0.89 \lambda / \beta \cos \theta$

Where $\lambda$ is wavelengths of X-ray radiation sutilized in $\AA, \theta$ is the diffractions angle, $\beta$ is the full width at half maximum (FWHM) in radians in the $2 \theta$ scale, $\mathrm{D}_{\mathrm{XRD}}$ is the crystallite sizes in $\mathrm{nm}$ [Cullity, 1967]. The crystallite size calculated from the diffraction pattern was decreased with increasing current density as shown in Table 2.

\section{Particle size:}

After that was the production of copper powder by electrodeposition process, calculated particle size at all values current density. Figures (7- a, b, c, d) as shown average particle size and distribution of copper particles, that results (table (2)) were exhibited the particles size reduced with increased current density because of the electro-crystallization of copper powder has two stages: "nucleation" and "growth". In the production of the powder each nucleus was represent powder particle, therefore, the amount of the powder can be obtained by changing the relative rate of nucleating and crystal growth. Increasing current density leds to more disperse structure of the powder particles. [M.G.Pavlovic, et al, 2010]

\section{CONCLUSIONS}

1- The production of highly efficient copper powder was done electrochemically.

2- The deposition of copper powder on the cathode electrode in the shape of fine layers.

3- The increase in current density of copper powder deposition leads to increase weight of copper powder deposition.

4- Dendritic shape was formed of copper particles.

5-X-Raydiffraction shows high crystallinity and high purity copper powder (without impurities or oxide).

6- The particle size of copper powder was decreased with increasing current density. 
Table (1) operating conditions for effecting current density.

\begin{tabular}{|c|c|c|c|c|c|}
\hline $\mathrm{CuSO}_{4} .5 \mathrm{H}_{2} \mathrm{O}$ & $\mathrm{H}_{2} \mathrm{SO}_{4}$ & $\mathrm{CuCl}_{2} .2 \mathrm{H}_{2} \mathrm{O}$ & Time & Distance & Current density \\
\hline $200 \mathrm{~g} / \mathrm{L}$ & $50 \mathrm{~g} / \mathrm{L}$ & $100 \mathrm{mg} / \mathrm{L}$ & $30 \mathrm{~min}$ & $2 \mathrm{~cm}$ & $\begin{array}{c}(0.12,0.14,0.16, \\
\end{array}$ \\
& & & & $0.18) \mathrm{Amp} / \mathrm{cm}^{2}$ \\
\hline
\end{tabular}

Table (2) Crystallite Size and Average Particle Size of Copper Powder

\begin{tabular}{|c|c|c|}
\hline $\begin{array}{c}\text { Current density } \\
\left(\mathrm{A} / \mathrm{cm}^{2}\right)\end{array}$ & $\begin{array}{c}\text { Crystallite Size } \\
(\mathrm{nm})\end{array}$ & $\begin{array}{c}\text { Particle Size } \\
(\mu \mathrm{m})\end{array}$ \\
\hline 0.12 & 38.44 & 8.72 \\
\hline 0.14 & 40.27 & 3.96 \\
\hline 0.16 & 40.46 & 3.59 \\
\hline 0.18 & 43.16 & 2.42 \\
\hline
\end{tabular}

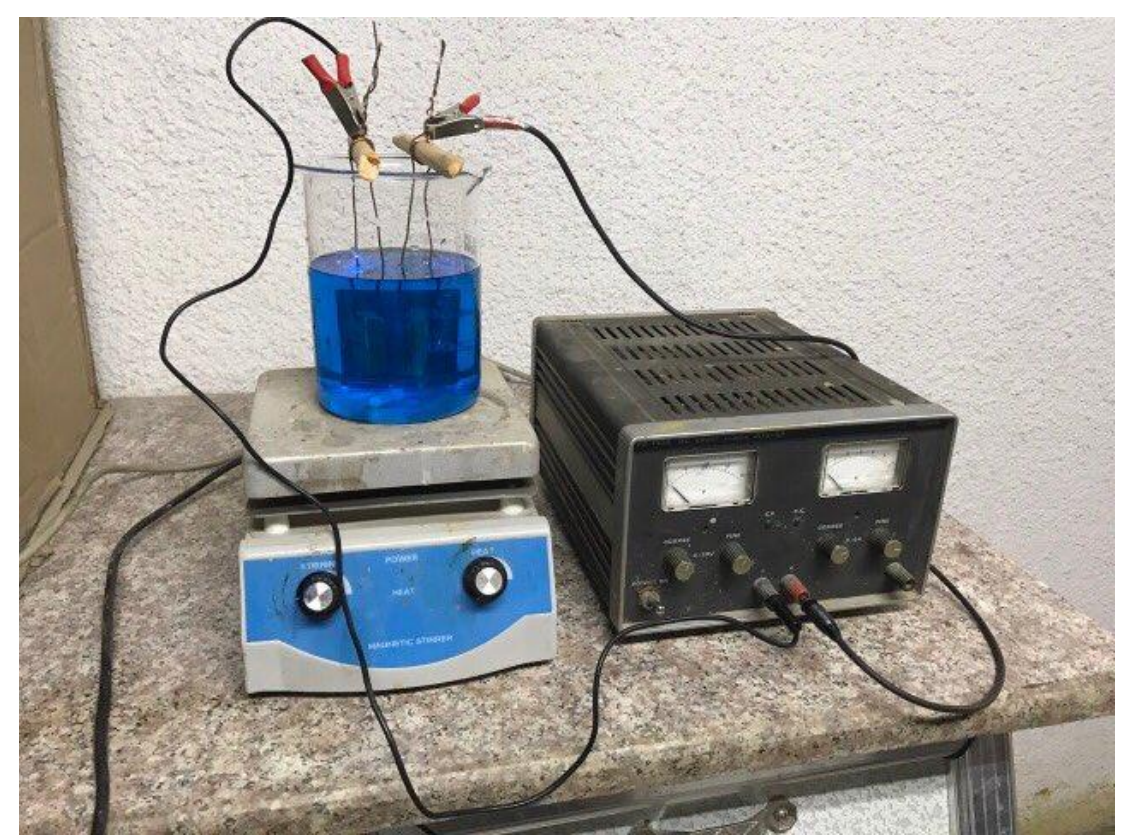

Fig (1) electrolytic cell used in the electrodeposition 


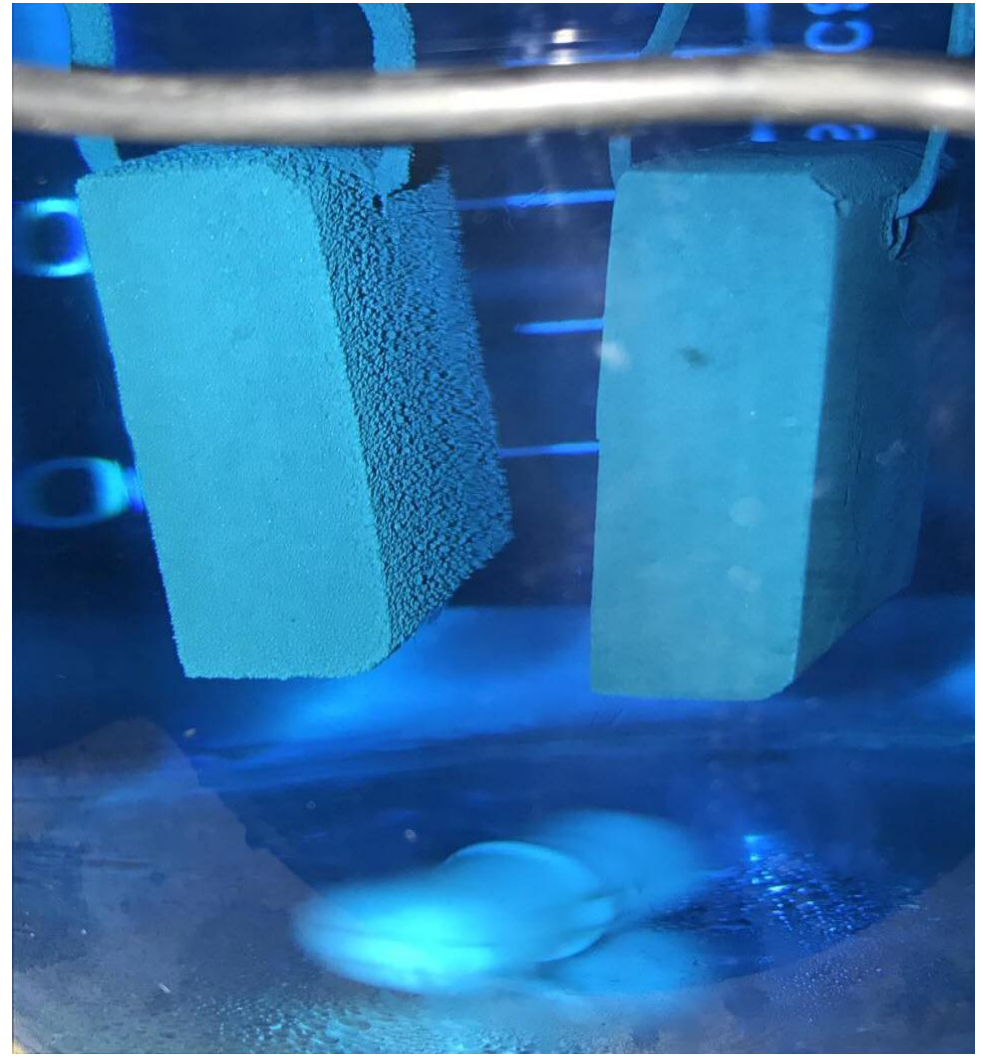

Fig (2) show deposited copper powder on surface of the cathode electrode

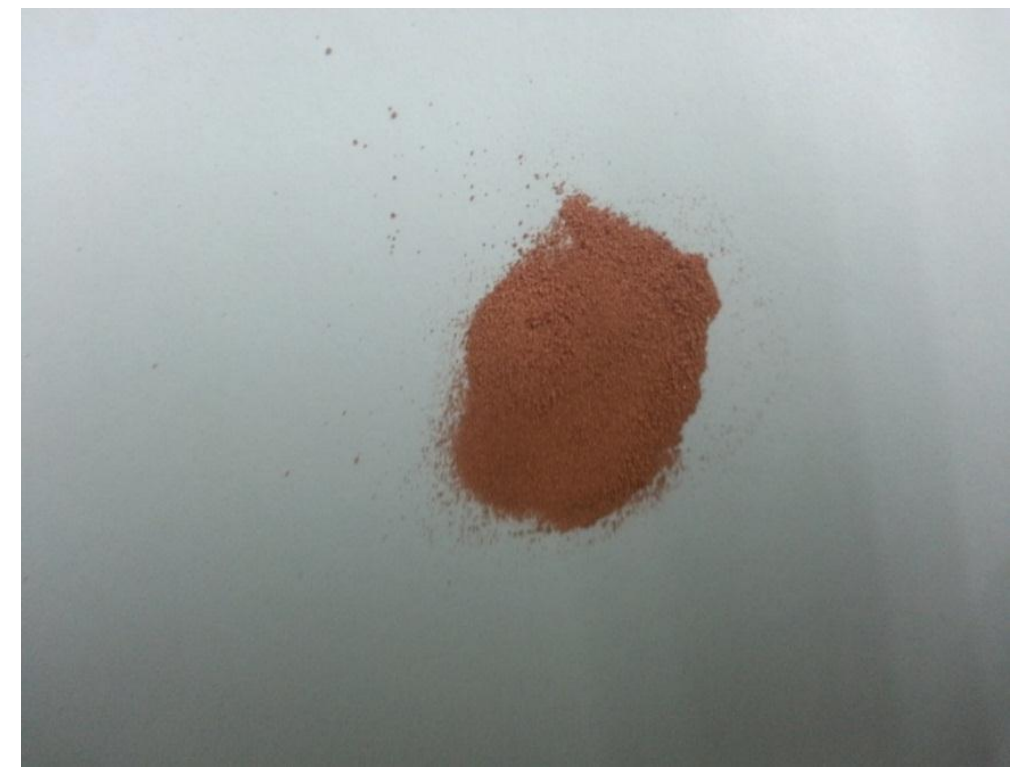

Fig (3) show deposited copper powder after electrodeposition process. 


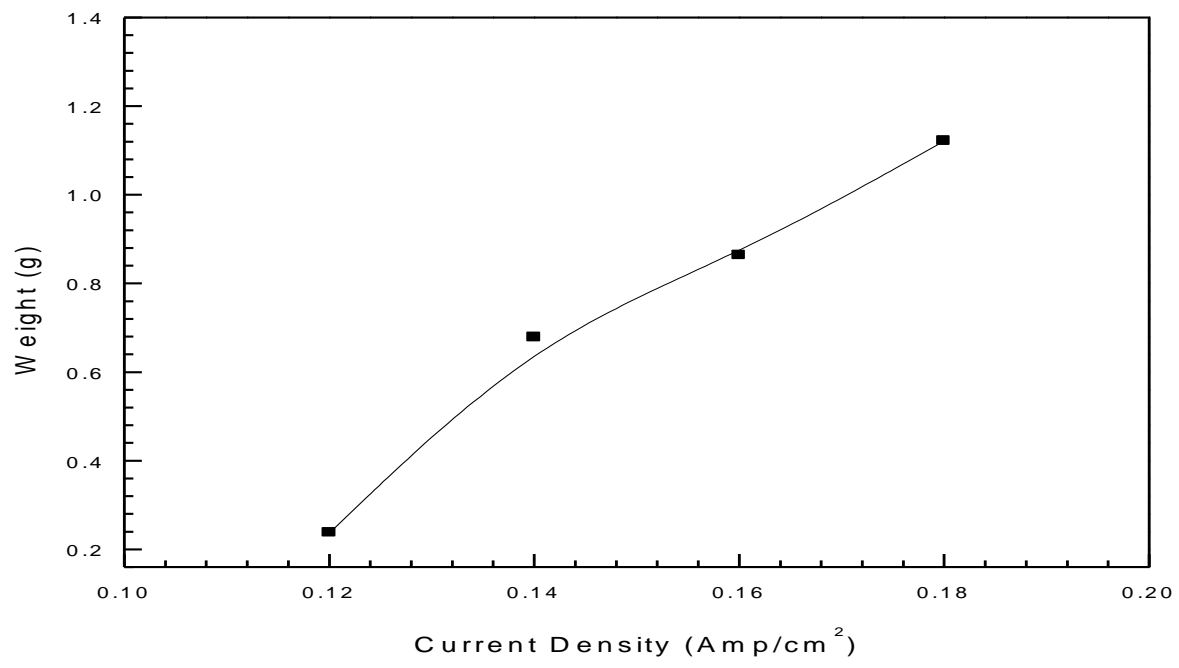

Figure (4) show relationship between current density and weight of deposited powder.

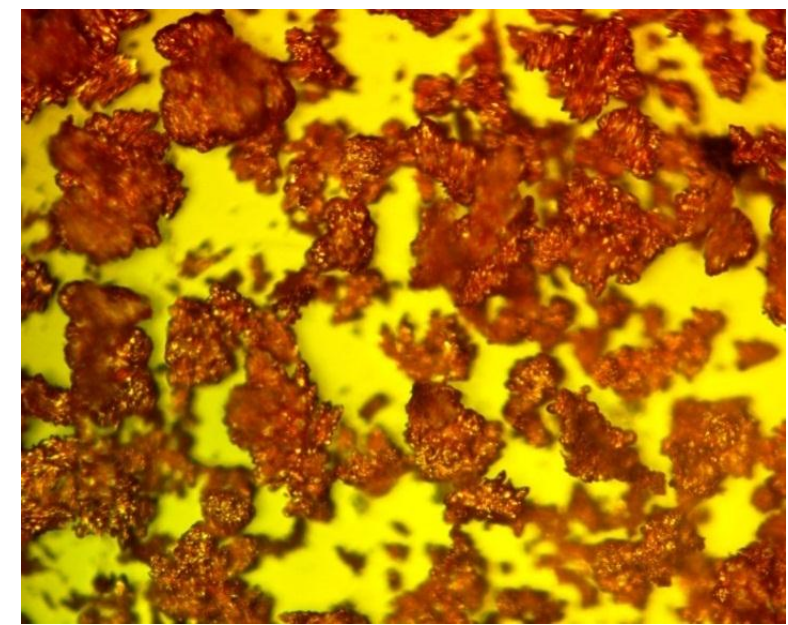

a- Particle shape at $0.12 \mathrm{~A} / \mathrm{cm}^{2}$

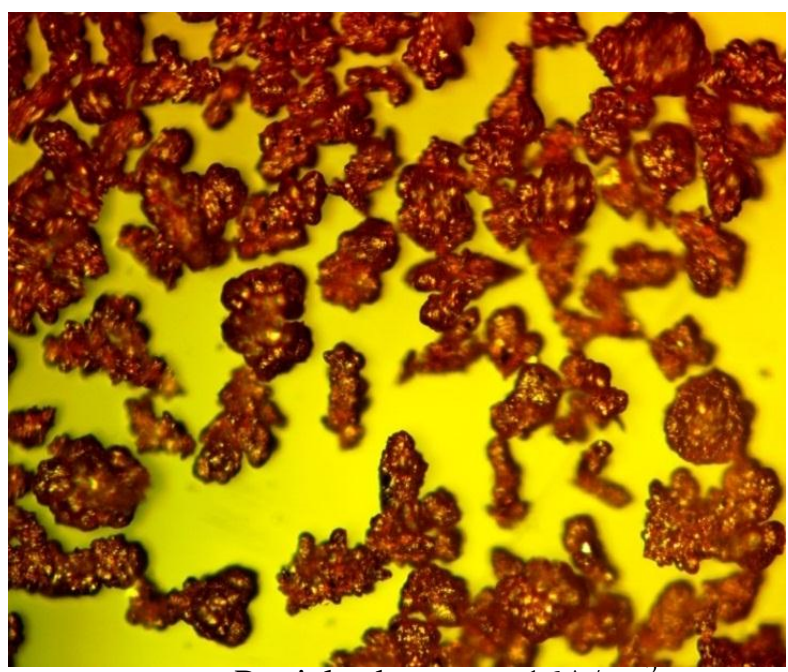

c- Particle shape at $0.16 \mathrm{~A} / \mathrm{cm}^{2}$

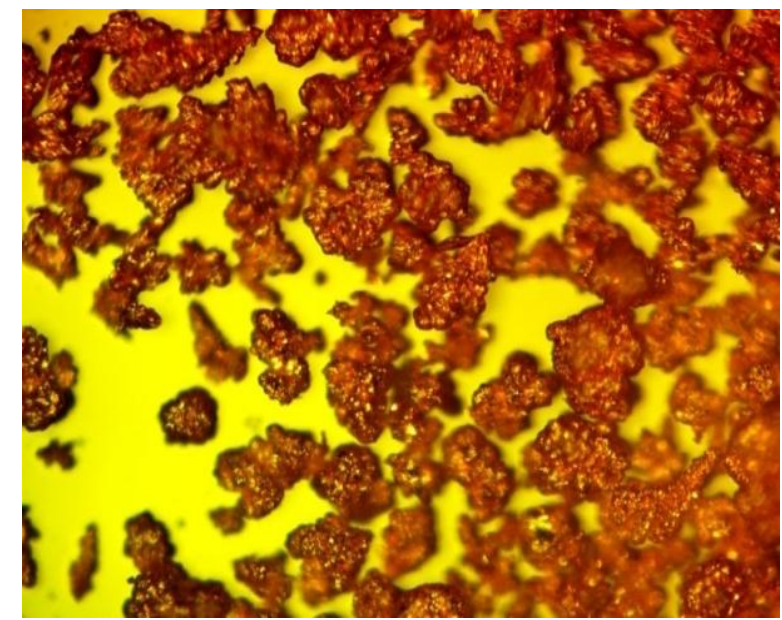

b- Particle shape at $0.14 \mathrm{~A} / \mathrm{cm}^{2}$

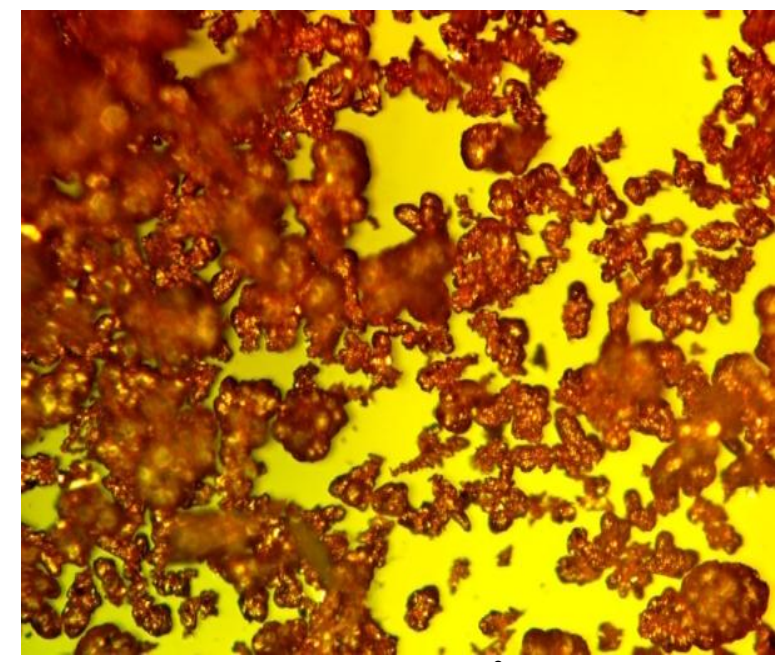

d- Particle shape at $0.18 \mathrm{~A} / \mathrm{cm}^{2}$

Fig (5) show dendritic shape of copper powder at different values of current density 
a

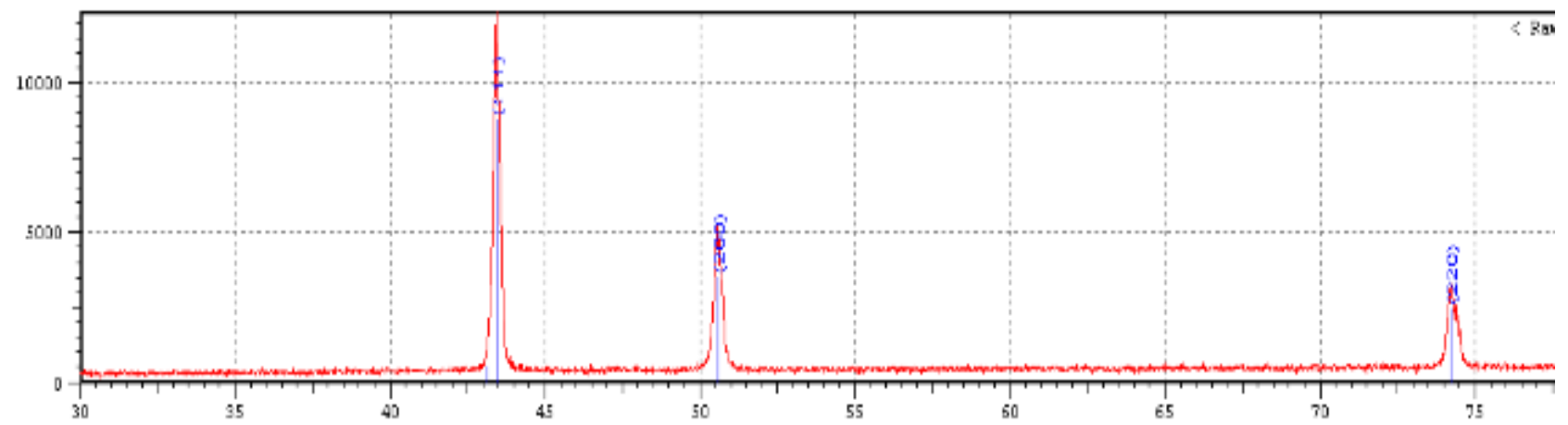

b
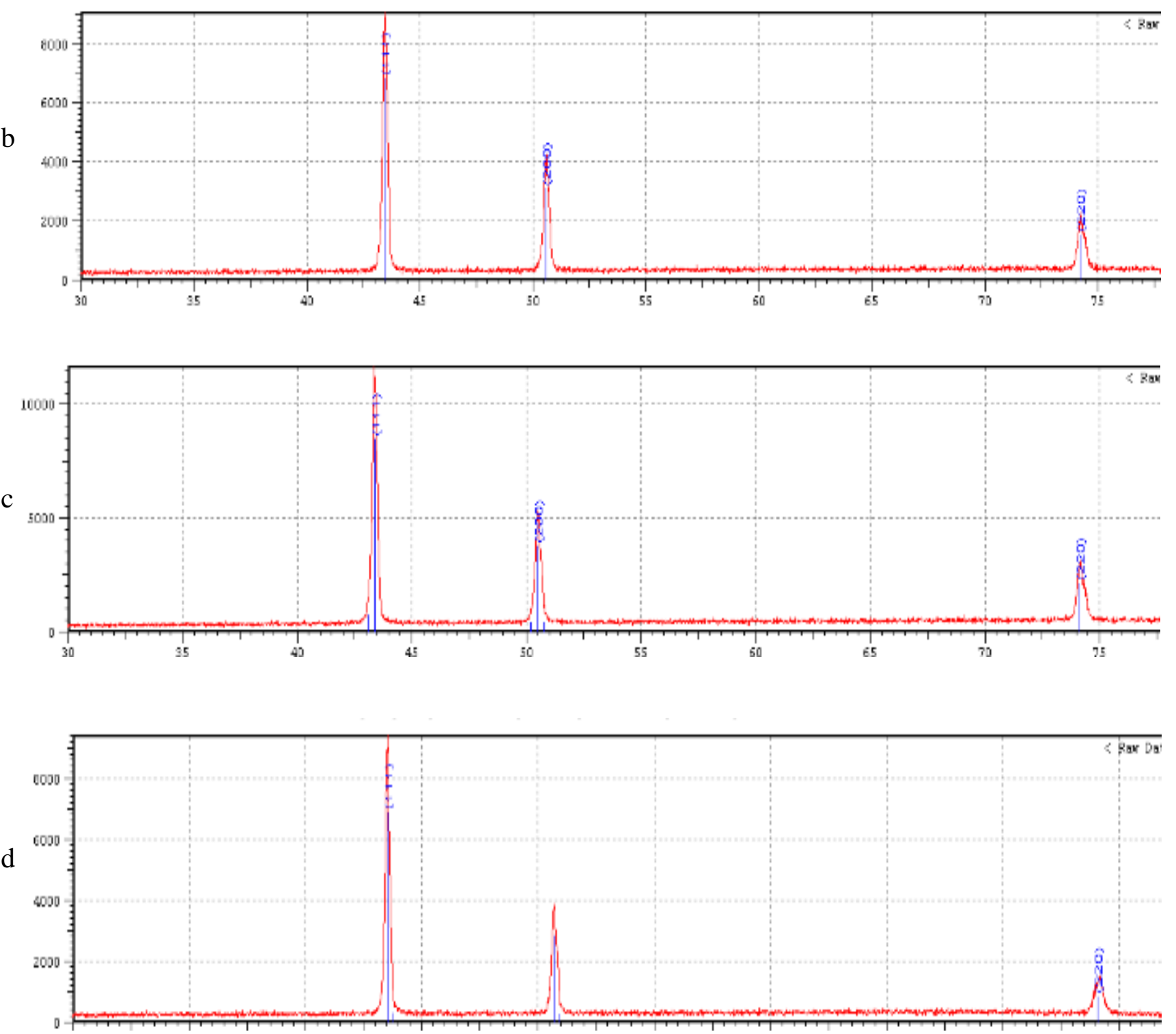

Fig (6) x-ray diffraction of pure copper that produced in electrodeposition 


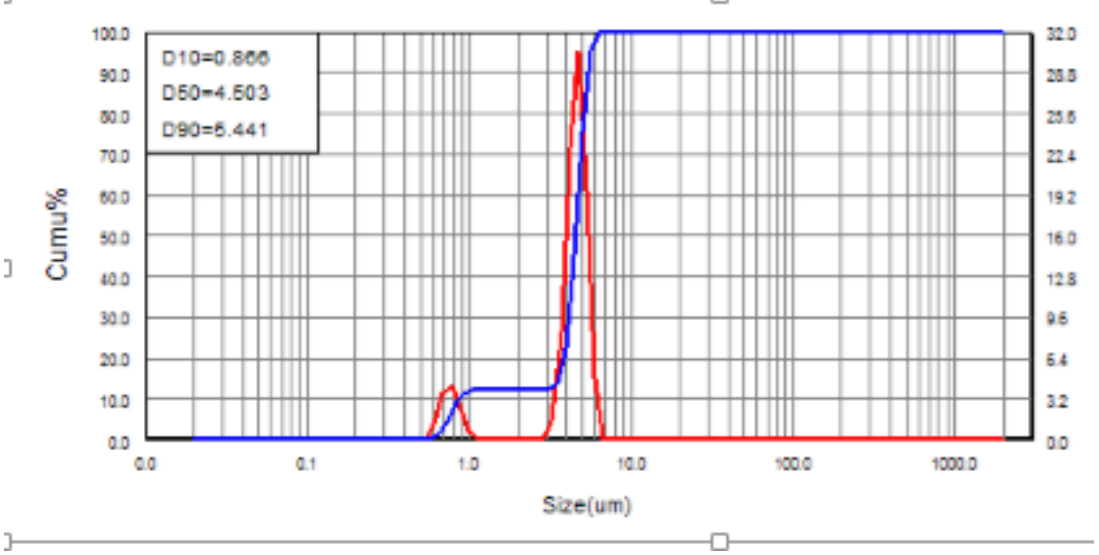

b

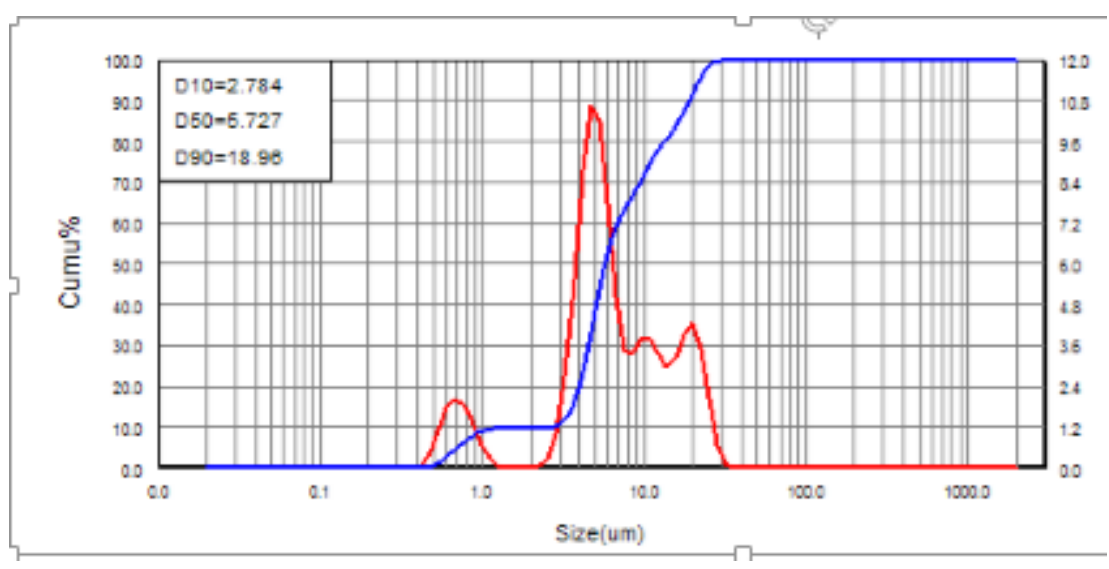

c
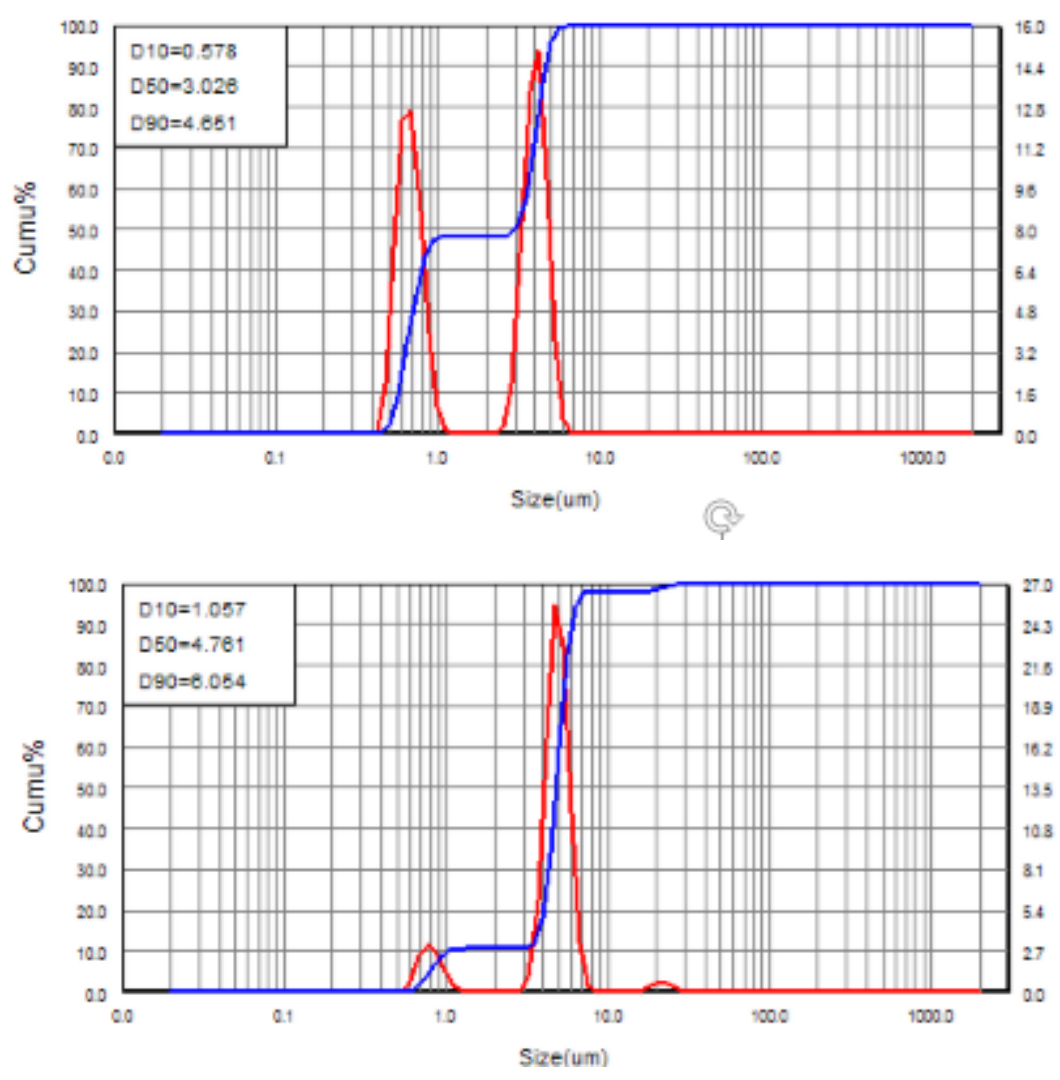

Fig (7) Particle size distribution of pure copper that produced in electrodeposition 


\section{REFERENCES:-}

-Ali H ,Abbar,Electrolytic preparation of copper powder with partical size less than $63 \mu \mathrm{m}$, mechanical engneering department, college of engineering, Al-Qadisiyia university, Vol.1, No.1, 2008 .

- M.G. pavlovic, LS.S pavlovic, V.M. Maksimovic, N.D. Nikollic and K.I. popov , characterization and morphology of copper powder particles as a function of different electrolytic regimes, university of Belgrade, in t.J.Electrochem. Sci , 5(2010)1862-1878.

- Muwafaq Mahdi Abd Al shammari, Experimental study of Zinc powder preparation by electrochemical method, college of engineering, Diyala university, Iraq, vol.07 , No.02 , pp.1$15,2014$.

- S.G. Viswanath, M.M.Jachak, Electrodeposition of copper powder from copper sulfate solution in presence of Glycerol and sulphric acid, Association of metallurgical engineers of Serbia, India, UDC:669-337,2012.

- Sundusabbas Jasim, production of copper and Zinc powders by using electrochemical process, Thesis, college of engineering, Babylon University, 2006.

- Wang Ming - Yong, Wang Zhi, Guo Zhan- chenge preparation of electrolytic copper powders with high current efficiency enhanced by super gravity filed and its mechanism, Transactions of non. Ferrous metals society china, 20(2010), 1154-1160.

-NouraTouabi ,sanja Martinez, Moussa Bounoughaz, Optimization of Electrochemical copper Recovery process:Effect of the Rotation speed in chloride medium of $\mathrm{PH}=3$,International journal of electrochemical science ,10(2015)7227-7240.

-Sami J Jafar ,Effects of New ADDITIVES (lanolin)on the electro-Deposition of copper powder ,Eng.Tech.Journal,university of Technology,Baghdad,Vol.27,No.12,2009.

- Cullity, B. D., 1967, Elements of X-ray Diffraction, London, Adison-Wesley Publ. Co.,

- S. Kumar, Sh. Pand, P. Verma, 2015, Factor Effecting Electro -Depostion Process, International Journal of Current Engineering and Technology, Uttaranchal Unversity, Dehradun, India, Vol.5, No.2. 